Prepared in cooperation with the Bureau of Reclamation

\title{
Groundwater Availability in the Truxton Basin, Northwestern Arizona
}

Chapter A of

Geophysical Surveys, Hydrogeologic Characterization, and Groundwater Flow Model for the Truxton Basin and Hualapai Plateau, Northwestern Arizona

Scientific Investigations Report 2020-5017-A 
Cover Background U.S. Geological Survey photograph showing an aerial view from central Truxton basin looking northwest. Music Mountains and Hualapai Plateau are in the center and right of photograph. Town of Truxton, Arizona, is in the lower left of photograph. Photograph by Jon Mason, September 2017.

Cover Inset. Three-dimensional perspective of the Truxton Basin Hydrologic Model viewing the Truxton basin and surrounding area from the south. 


\section{Groundwater Availability in the Truxton Basin, Northwestern Arizona}

By Jon P. Mason, Jacob E. Knight, Lyndsay B. Ball, Jeffery R. Kennedy, Donald J. Bills, and Jamie P. Macy

Chapter A of

Geophysical Surveys, Hydrogeologic Characterization, and Groundwater Flow Model for the Truxton Basin and Hualapai Plateau, Northwestern Arizona

Edited by Jon P. Mason

Prepared in cooperation with the Bureau of Reclamation

Scientific Investigations Report 2020-5017-A 


\title{
U.S. Department of the Interior DAVID BERNHARDT, Secretary
}

\author{
U.S. Geological Survey \\ James F. Reilly II, Director
}

U.S. Geological Survey, Reston, Virginia: 2020

For more information on the USGS - the Federal source for science about the Earth, its natural and living resources, natural hazards, and the environment-visit https://www.usgs.gov or call 1-888-ASK-USGS.

For an overview of USGS information products, including maps, imagery, and publications,

visit https://store.usgs.gov.

Any use of trade, firm, or product names is for descriptive purposes only and does not imply endorsement by the U.S. Government.

Although this information product, for the most part, is in the public domain, it also may contain copyrighted materials as noted in the text. Permission to reproduce copyrighted items must be secured from the copyright owner.

Suggested citation:

Mason, J.P., Knight, J.E., Ball, L.B. Kennedy, J.R., Bills, D.J., and Macy, J.P., 2020, Groundwater availability in the Truxton basin, northwestern Arizona, chap. A of Mason, J.P., ed., Geophysical surveys, hydrogeologic characterization, and groundwater flow model for the Truxton basin and Hualapai Plateau, northwestern Arizona: U.S. Geological Survey Scientific Investigations Report 2020-5017, 14 p., https://doi.org/10.3133/sir20205017A.

ISSN 2328-0328 (online) 


\section{Preface}

This is the third and final report in a series describing the groundwater resources of the Hualapai Indian Reservation. These reports document the findings of a comprehensive groundwater study conducted on the reservation and adjacent areas from 2015 through 2018 by the U.S. Geological Survey in cooperation with the Bureau of Reclamation. The first report described the hydrologic framework and characterization of the Truxton aquifer on the Hualapai Indian Reservation (Bills and Macy, 2016). The second report described the hydrogeologic characterization of the Hualapai Plateau part of the reservation (Mason, Macy, and others, 2020). This report includes five chapters. Chapter A (this report) is a summary of this multichapter volume, including a brief description of the study area and hydrogeologic framework of the Truxton aquifer, description of the numerical groundwater-flow model developed to simulate groundwater levels in the aquifer, and estimates of simulated changes to groundwater levels in the aquifer based on projected groundwater withdrawals. Chapter B (Mason, Bills, and Macy, 2020) describes the geology and hydrology of the Truxton basin and Hualapai Plateau. Chapter C

(Kennedy, 2020) describes the results of a gravity geophysical survey of the Truxton basin. Chapter D (Ball, 2020) describes the findings of an airborne electromagnetic survey of the Truxton aquifer and Hualapai Plateau. Chapter E (Knight, 2020) describes the results of a transient groundwater model created for the entire Truxton aquifer both on and off the reservation. The groundwater-flow model is used to estimate projected groundwater levels based on future groundwater withdrawal scenarios. 


\section{Contents}

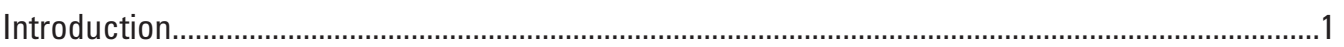

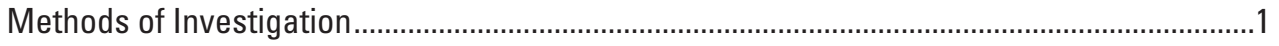

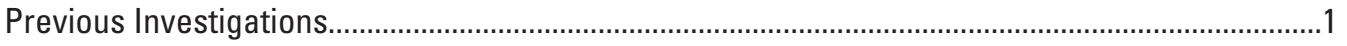

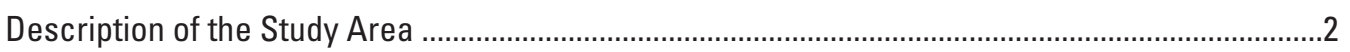

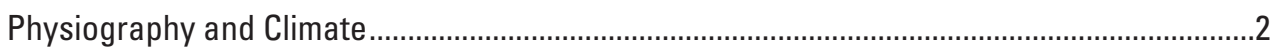

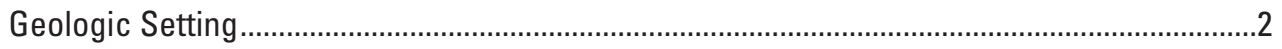

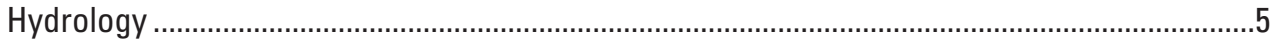

Conceptual Model of the Truxton Basin Groundwater System........................................................

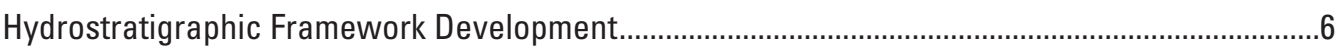

Simulation of Current Conditions and Changes to the Truxton Aquifer ............................................

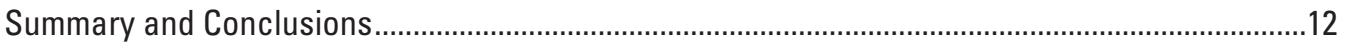

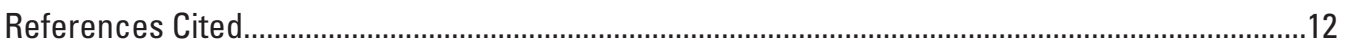

\section{Figures}

1. Map of the study area in northwestern Arizona showing the approximate boundaries of the Truxton basin, Music Mountains, and the Hualapai Plateau.

2. Maps showing the 30-year average annual temperature and average annual precipitation and average annual evaporation in the study area ....................................

3. Map showing well and spring locations and observation zones simulated in the Truxton Basin Hydrologic Model...............................................................................7

4. Scatterplot graph showing estimated versus simulated groundwater heads, plotted by hydrostratigraphic unit.

5. Map showing head target residuals (estimated minus simulated), in feet, from the calibrated Truxton Basin Hydrologic Model

6. Bar graph showing estimated flux targets and simulated equivalents of total groundwater discharge by flux-observation zone

7. Map showing Truxton Basin Hydrologic Model simulated groundwater head contours and flow directions.

8. Map showing simulated drawdown from 2020 to 2140 for the high pumping scenario using the primary bedrock depth, in feet, and simulated pumping rates at Truxton well field and proposed new well in the high pumping scenario

9. Boxplot diagrams showing the distribution of simulated groundwater level decline from 2020 levels for the high pumping scenario using the medium bedrock depth model at year 2070 and year 2140 at five pumping scenario locations in the Truxton basin

\section{Tables}

1. Estimated predevelopment groundwater-budget values for western Hualapai Plateau, eastern Hualapai Plateau, and Truxton basin 


\section{Conversion Factors}

U.S. customary units to International System of Units

\begin{tabular}{lcl}
\hline \multicolumn{1}{c}{ Multiply } & By & \multicolumn{1}{c}{ To obtain } \\
\hline inch (in.) & Length & \\
inch (in.) & 2.54 & centimeter $(\mathrm{cm})$ \\
foot (ft) & 25.4 & millimeter $(\mathrm{mm})$ \\
mile (mi) & 0.3048 & meter $(\mathrm{m})$ \\
\hline & 1.609 & kilometer $(\mathrm{km})$ \\
\hline acre & Area & \\
acre & 4,047 & square meter $\left(\mathrm{m}^{2}\right)$ \\
square mile (mi $\left.{ }^{2}\right)$ & 0.4047 & hectare $($ ha) \\
\hline & 2.590 & square kilometer $\left(\mathrm{km}^{2}\right)$ \\
\hline gallon (gal) & Volume & \\
acre-foot (acre-ft) & 0.003785 & cubic meter $\left(\mathrm{m}^{3}\right)$ \\
acre-foot (acre-ft) & 1,233 & cubic meter $\left(\mathrm{m}^{3}\right)$ \\
\hline & 0.001233 & cubic hectometer $\left(\mathrm{hm}^{3}\right)$ \\
\hline acre-foot per year (acre-ft/yr) & Flow rate & \\
gallon per minute (gal/min) & 1,233 & cubic meter per year $\left(\mathrm{m}^{3} / \mathrm{yr}\right)$ \\
gallon per day (gal/d) & 0.06309 & liter per second $(\mathrm{L} / \mathrm{s})$ \\
\hline
\end{tabular}

Temperature in degrees Celsius $\left({ }^{\circ} \mathrm{C}\right)$ may be converted to degrees Fahrenheit $\left({ }^{\circ} \mathrm{F}\right)$ as

$$
{ }^{\circ} \mathrm{F}=\left(1.8 \times{ }^{\circ} \mathrm{C}\right)+32 .
$$

Temperature in degrees Fahrenheit $\left({ }^{\circ} \mathrm{F}\right)$ may be converted to degrees Celsius $\left({ }^{\circ} \mathrm{C}\right)$ as

$$
{ }^{\circ} \mathrm{C}=\left({ }^{\circ} \mathrm{F}-32\right) / 1.8 \text {. }
$$

\section{Datum}

Vertical coordinate information is referenced to the National Geodetic Vertical Datum of 1929 (NGVD 29) and North American Vertical Datum of 1988 (NAVD 88)

Horizontal coordinate information is referenced to the North American Datum of 1983 (NAD 83).

Elevation, as used in this report, refers to distance above the vertical datum. 


\section{Abbreviations}

$\begin{array}{ll}\text { ADWR } & \text { Arizona Department of Water Resources } \\ \text { AEM } & \text { airborne electromagnetic } \\ \text { EPA } & \text { U.S. Environmental Protection Agency } \\ \mathrm{ft} & \text { feet } \\ \text { HDNR } & \text { Hualapai Department of Natural Resources } \\ \mathrm{m} & \text { meters } \\ \text { NRCE } & \text { Natural Resources Consulting Engineers } \\ \text { ppm } & \text { parts per million } \\ \text { Reclamation } & \text { Bureau of Reclamation } \\ \text { TBHM } & \text { Truxton Basin Hydrologic Model } \\ \text { USGS } & \text { U.S. Geological Survey }\end{array}$




\title{
Groundwater Availability in the Truxton Basin, Northwestern Arizona
}

\author{
By Jon P. Mason, Jacob E. Knight, Lyndsay B. Ball, Jeffery R. Kennedy, Donald J. Bills, and Jamie P. Macy
}

\section{Introduction}

The Hualapai Tribe of northwestern Arizona is seeking reliable and sustainable water resources to meet the projected long-term needs for the reservation. In cooperation with the Federal Indian Water-Rights Negotiation Team and the Bureau of Reclamation (Reclamation), the U.S. Geological Survey (USGS) has conducted a series of investigations on and near the Hualapai Indian Reservation to evaluate groundwater resources in the area. Three reports document the findings from these comprehensive groundwater studies conducted from 2015 through 2018. The first report published in 2016 described the hydrologic framework and characterization of the Truxton aquifer on the Hualapai Indian Reservation (Bills and Macy, 2016). The second report described the hydrogeologic characterization of the Hualapai Plateau part of the reservation (Mason, Macy, and others, 2020). The current and final report in the series is focused on the availability of groundwater in the Truxton aquifer both on and adjacent to the Hualapai Indian Reservation. This chapter is a summary of a multichapter volume (five chapters), consisting of a brief description of the study area and hydrogeologic framework of the Truxton aquifer, description of the numerical groundwater-flow model developed to simulate groundwater levels in the aquifer, and estimates of simulated changes to groundwater levels in the aquifer based on projected groundwater withdrawals. Mason, Bills, and others (2020) details the geology and hydrology of the study area. Kennedy (2020) and Ball (2020) describe new geophysical data collected to improve the hydrostratigraphic framework necessary for estimating the total storage of the Truxton aquifer and to improve simulation of the groundwater system. Kennedy (2020) presents the results of a Truxton basin gravity survey. Ball (2020) describes the acquisition, processing, and interpretation of an airborne electromagnetic survey of the Truxton basin and Hualapai Plateau. Knight (2020) documents the development of a transient groundwater-flow model of the Truxton aquifer both on and off the reservation, including details on model construction and calibration. The groundwater-flow model is used to estimate projected groundwater levels based on future groundwater withdrawal scenarios.

\section{Methods of Investigation}

This assessment of groundwater availability in the Truxton aquifer consisted of collection, integration, and use of both new and existing data along with the development and calibration of a new groundwater-flow model. The groundwater-flow model is the primary tool used to evaluate the potential future conditions of the Truxton aquifer groundwater system in this investigation. Data used in this study include groundwater levels, groundwater pumping rates and volumes, rate of groundwater discharge at spring sites, and new hydrostratigraphy developed for the area of this study. These data are used to construct and calibrate the groundwater-flow model. A finite-difference numerical groundwater-flow model was developed to simulate groundwater flow in the Truxton aquifer over the 1976-2140 time period, with a primary goal of evaluating possible changes in the groundwater system resulting from projected increases in groundwater pumping from the aquifer.

\section{Previous Investigations}

Prior to this groundwater study, several investigations were completed related to the geology and hydrology of the Hualapai Indian Reservation and adjacent areas. Early reconnaissance work on the geology of the Hualapai Indian Reservation was conducted by USGS geologists (Dutton 1882a, b; Lee, 1908; Schrader, 1909; Darton, 1910, 1915, 1925; McKee, $1934,1938,1945)$. Other early researchers who worked in this area include Koons $(1945$; 1948a, b), who described the geology of the Hualapai Indian Reservation proceeding westward from the eastern Grand Canyon. The Arizona Geological Survey produced a geologic map of Mohave County in 1959 and a geologic map of Arizona in 1969, which has been revised several times since (Wilson and Moore, 1959; Reynolds, 1997; Richards and others, 2000). In 1942, the USGS worked with the Hualapai Tribe to locate and evaluate sites for the development of livestock water on the reservation (H.V. Peterson, USGS, written commun., 1942). In 1962, the USGS evaluated the geology and promising areas for groundwater development 
on the Hualapai Indian Reservation (Twenter, 1962). Throughout the 1970s and 1980s, the Arizona Department of Water Resources (ADWR) and USGS cooperated on a series of groundwater condition maps for Arizona. Two of these maps most relevant to this study are groundwater conditions of the Hualapai Basin and groundwater conditions of the Peach Springs Basin (Remick, 1981; Myers, 1987). In the mid1980s, the USGS developed generalized distribution of aquifer material and predevelopment hydrologic conditions maps for alluvial basins of Arizona and adjacent areas (Freethey and others, 1986; Freethey and Anderson, 1986). In the mid-1990s, the USGS began a water-resources assessment of the Hualapai Indian Reservation. As part of this study, the USGS and the Hualapai Department of Natural Resources (HDNR) visited, measured flow rates, and collected water samples from most of the springs and selected wells on the reservation (Hualapai Water Resources Program, 1999, 2004, 2009). The USGS reevaluated the surface geology and geologic structure of the Hualapai Indian Reservation in relation to mineral resource potential in the mid-1990s (Billingsley and others, 1986, 1999; Wenrich and others, 1996, 1997).

Since 2000, the Hualapai Tribe has worked with private consultants and Federal agencies to develop a series of waterresource assessments and water-management plans. These studies were designed to provide the tribe with better information on the quantity and quality of water on the reservation and identify strategies to meet current and future water needs. Young (2007) described perched groundwater resources contained in the river gravels and semiconsolidated sediments of the West Water Canyon area, to the north of the Truxton basin. Working with Reclamation, HDNR completed water management plans for the western Hualapai Plateau and Spencer creek watersheds and the Truxton Wash and Peach Springs Canyon watersheds, respectively (Hualapai Department of Natural Resources, 2010, 2015). Natural Resources Consulting Engineers (NRCE) provided the Hualapai Tribe with an evaluation of the community of Peach Springs groundwater supply to describe the adequacy of the existing water-supply system to meet current domestic, commercial, and municipal water needs and recommend action to expand the water supply system (Natural Resources Consulting Engineers, 2011). As described previously, two reports documenting the hydrologic framework and characterization of the Truxton aquifer (Bills and Macy, 2016) and the hydrogeology of the Hualapai Plateau part of the reservation (Mason, Macy, and others, 2020) were recently published. Bills and Macy (2016) provides a more detailed summary of investigations conducted prior to 2016.

\section{Description of the Study Area}

The study area for this investigation consists of the Truxton basin and the adjacent Music Mountains and Hualapai Plateau in northwestern Arizona (fig. 1). All of the study area lies within or is adjacent to the Hualapai Indian Reservation.
Introductory discussion of the study area is provided here with additional details included in Mason, Bills, and others (2020).

\section{Physiography and Climate}

The Truxton basin is a relatively small, 75 square mile topographic depression bordered to the north and east by the Hualapai Plateau and to the south and west by the Cottonwood Mountains (fig. 1). The basin is located at the northern edge of the Transition Zone in Arizona, which is a transition between the mostly flat-lying, layered sedimentary rocks of the Colorado Plateau to the northeast and the heavily faulted, folded, and eroded Basin and Range Province to the west and south (Fenneman, 1931). The Truxton basin has an average elevation of 4,300 feet (ft; Twenter, 1962). The Music Mountains form the southwestern rim and are the highest point of the Hualapai Plateau at over $6,700 \mathrm{ft}$. The central part of the plateau has an average elevation of about 5,000 ft (Twenter, 1962). Erosion of the Paleozoic section from the Truxton basin is the primary reason for the difference in elevation between the two physiographic features, although structural deformation along faults and monoclines are at play in both areas.

The climate of the study area is classified as arid at lower elevations to semiarid at higher elevations. Hualapai Indian Reservation average annual temperatures vary, in degrees Fahrenheit $\left({ }^{\circ} \mathrm{F}\right)$, from the mid-50s to the mid-60s depending on elevation (fig. 2). Temperature extremes of $110^{\circ} \mathrm{F}$ in the summer and near $0^{\circ} \mathrm{F}$ in the winter have been recorded (PRISM Climate Group, 2020). Much of the precipitation occurs during isolated monsoonal thunderstorms in the summer (Western Region Climate Center, 2015). Accumulations of snow can occur in the winter, especially at higher elevations. Occasional warm winter storms that produce rain on snow have resulted in large runoff events in the Peach Springs basin (Sellers and others, 1985; Arizona Department of Water Resources, 2009). As with other areas of the Colorado Plateau, the Hualapai Indian Reservation experiences drought conditions that can last for several years to decades interspersed with or followed by much shorter periods of above normal to extremely wet weather. The climate of the study area is described in greater detail in Bills and Macy (2016).

\section{Geologic Setting}

The Truxton basin and Hualapai Plateau were likely very similar geologically prior to the Laramide uplift in the Late Cretaceous and Paleogene. Erosion during and after regional uplift removed Mesozoic deposits from the entire area and further removed Paleozoic deposits from most of the Truxton basin. Tertiary volcanism affected both areas, whereas Tertiary and Quaternary sedimentation further changed the Truxton basin.

The base of the Truxton aquifer is delineated by Proterozoic crystalline and metamorphic rock that are generally not considered an aquifer in the area. The bulk of geologic 


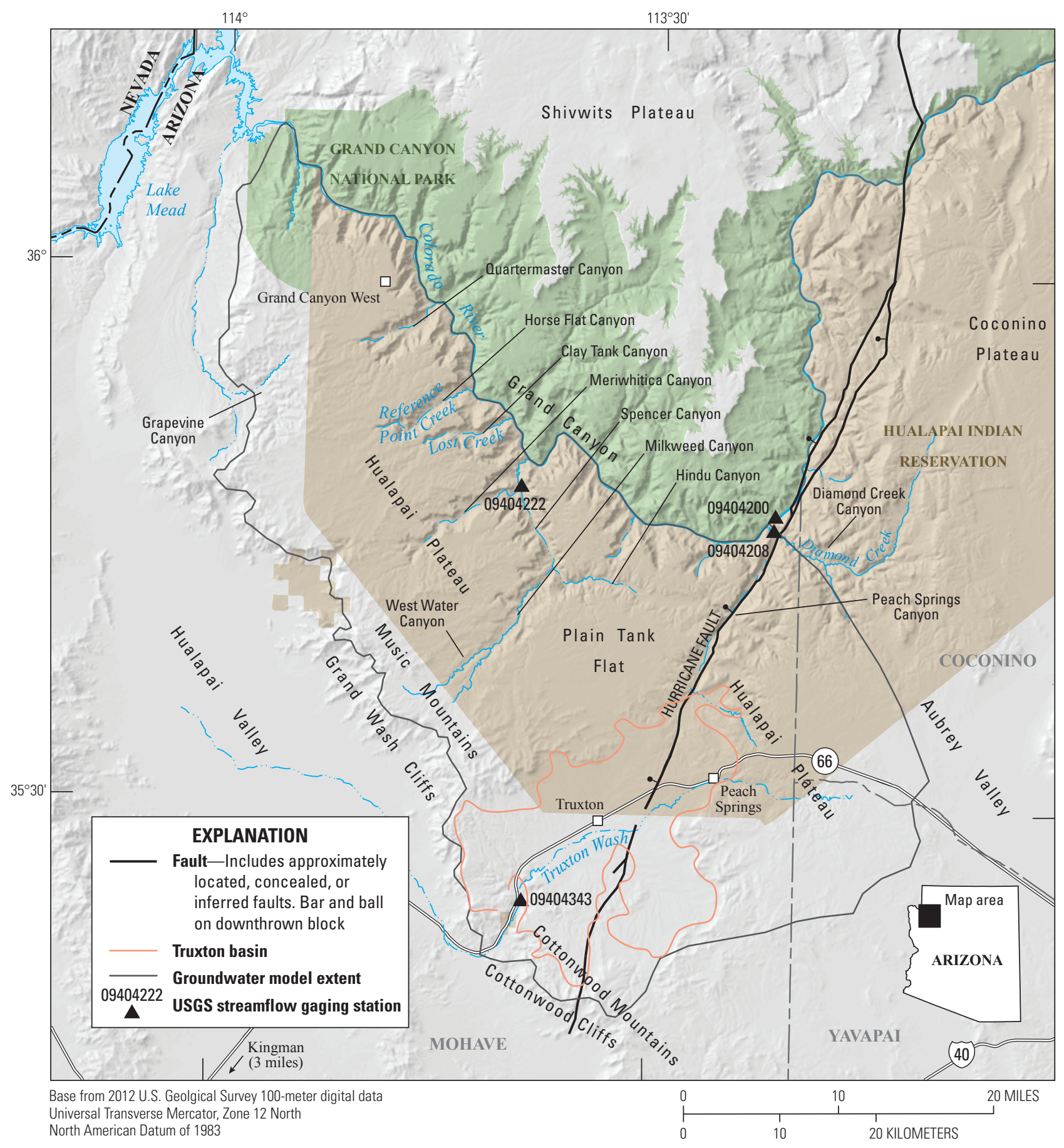

Figure 1. Map of the study area in northwestern Arizona showing the approximate boundaries of the Truxton basin, Music Mountains, and the Hualapai Plateau. Faults modified from Arizona Bureau of Geology and Mineral Technology (1988), Beard and Lucchitta (1993), Billingsley and others (2006), and Richard and others (2000). 


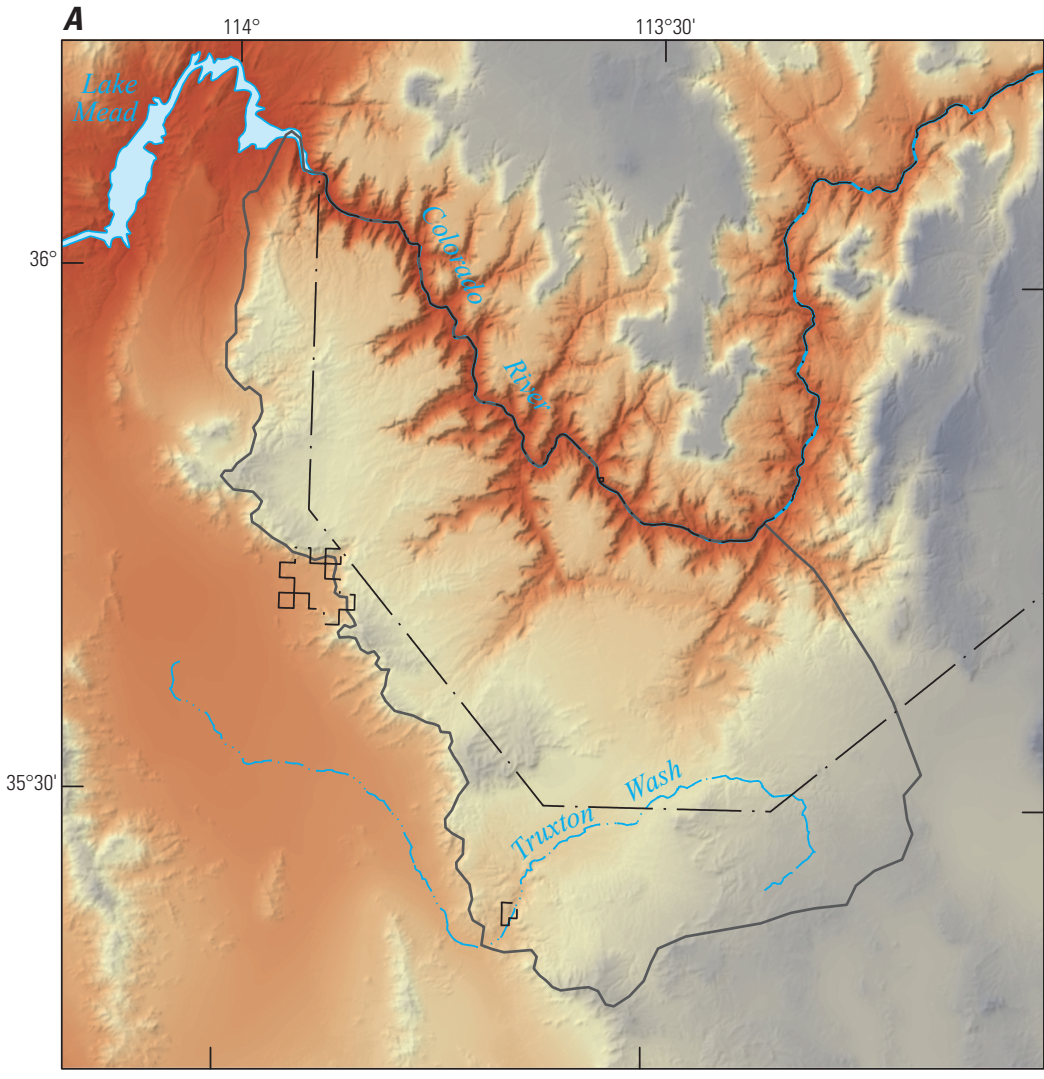

B

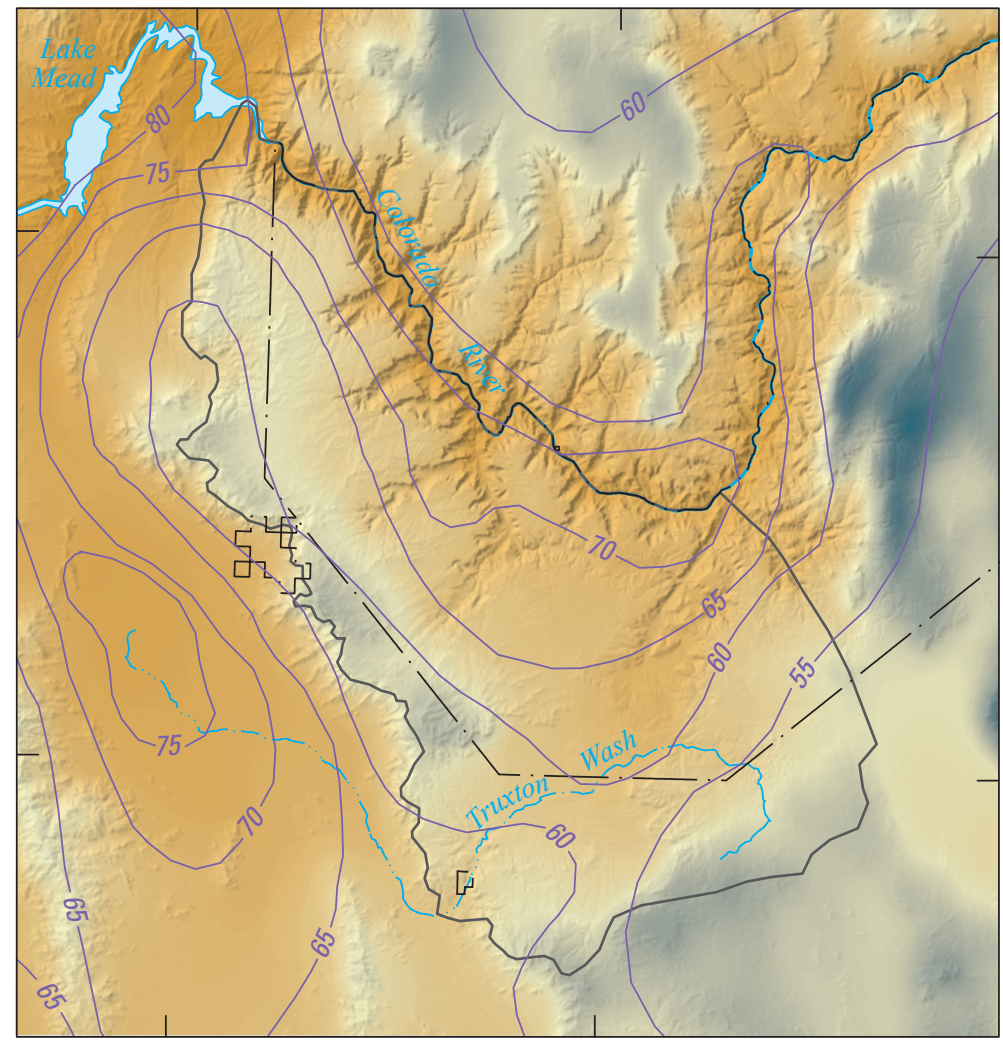

Base from 2012 U.S. Geolgical Survey 100-meter digital data Universal Transverse Mercator, Zone 12 North North American Datum of 1983

\section{EXPLANATION}

Mean annual temperature, 1981-2010, in degrees Fahrenheit

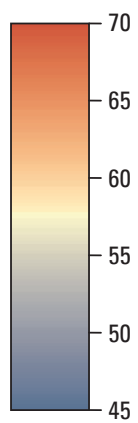

—- - Hualapai Indian Reservation
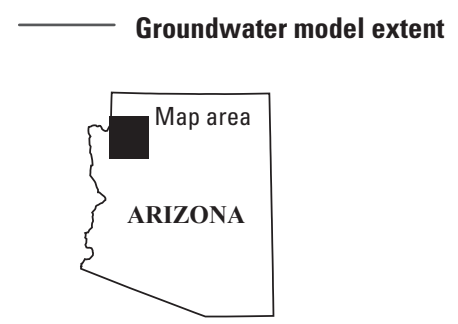

Data from PRISM Climate Group, Oregon State University, http://prism.oregonstate.edu, accessed January 29, 2020.

\section{EXPLANATION}

Mean annual precipitation, 1981-2010, in inches per year

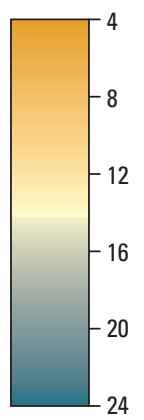

\section{-65- Annual free-water-surface evaporation, in inches \\ - - Hualapai Indian Reservation \\ - Groundwater model extent}

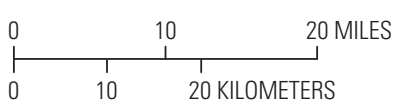

Data from PRISM Climate Group, Oregon State University, http://prism.oregonstate.edu, accessed January 29, 2020 Evaporation data from Farnsworth and others (1982)

Figure 2. Maps showing the 30-year average annual temperature $(A)$ and average evaporation $(B)$ in the study area, northwestern Arizona. 
units above the Proterozoic consist of Tertiary and Quaternary basin-fill deposits with some intervening Cambrian rock units present on the east end of the basin. Bills and Macy (2016) divided Truxton basin-fill deposits into the younger basin-fill sediments and older basin-fill sediments based on age, the degree of consolidation, and how likely sediments were to be saturated. The younger basin-fill sediments are a sequence of Quaternary unconsolidated to semiconsolidated sand, gravel, clay, and silt that are tan, light brown to reddish-brown. The younger basin-fill sediments are typically dry except near the base of the unit as observed in a few wells (Bills and Macy, 2016). Interbeds of volcanic deposits were observed below the younger basin-fill sediments in some wells. Where observed in wells, the volcanic rocks are typically fully saturated, although they yield little to no water to wells (Bills and Macy, 2016). The older basin-fill sediments in Truxton basin consist of a sequence of partly consolidated to consolidated, reddishbrown to brown gravel and sand with varying amounts of clay. These sediments are almost always fully saturated and represent the main part of the Truxton aquifer (Bills and Macy, 2016). The total thickness of basin-fill sediments and volcanic deposits vary widely throughout the Truxton basin, from thin to absent in the south to more than 500 meters $(\mathrm{m})$ towards the center of the basin. Thicker sediments are typically associated with buried paleocanyons and the western footwall of the Hurricane Fault (Elston and Young, 1991).

The basement rock of the Hualapai Plateau is similar to the Proterozoic crystalline and metamorphic rocks that underlie the Truxton basin. Above the basement rock lies the Tonto Group: the Tapeats Sandstone, Bright Angel Shale, and Muav Limestone. The Tapeats Sandstone includes medium- to coarse-grained sandstone, conglomerate, and shale and lies unconformably on the Proterozoic basement rock. The Bright Angel Shale conformably overlies the Tapeats Sandstone and consists of siltstone and shale with thin beds of sandstone and dolomite. The Muav Limestone conformably overlies the Bright Angel Shale and comprises limestone, dolomite, and calcareous mudstone. The Devonian Temple Butte Formation unconformably overlies the Muav Limestone on the Hualapai Plateau and consists of mudstone, sandstone, dolomite, and conglomerate-filled channels eroded into the underlying Cambrian strata (Billingsley and others, 2006). The Mississippian Redwall Limestone crops out at or near the surface on much of the Hualapai Plateau, is several hundred feet thick in many locations, and consists of limestone, fossiliferous limestone, oolitic limestone, dolomite, fossiliferous dolomite, and chert beds (Billingsley and others, 2006). The uppermost Paleozoic units found on the Hualapai Plateau are the Upper Mississippian to Upper Pennsylvanian Watahomigi, Manakacha, and Wescogame Formations (members of the Supai Group). No Paleozoic rocks are above the Supai Group on the Hualapai Plateau. Tertiary deposits on the plateau consist mainly of andesite and basalt lava flows and sedimentary gravel deposits. The gravel deposits occur mainly in stream valleys and across much of Plain Tank Flat. Quaternary deposits on the plateau include stream channel, valley fill, travertine, landslide, and alluvial fan deposits (Billingsley and others, 2006).

\section{Hydrology}

Most surface-water drainages in the study area are ephemeral and flow only in response to substantial precipitation events. A few drainages have perennial reaches that are supported by groundwater discharge from springs. Truxton Wash (figs.1,2) is the principal drainage of the Truxton basin and often flows for a short reach at the west end of the basin where it has eroded a channel through the basin sediments into impermeable granitic basement rocks. Principal drainages of the Hualapai Plateau are Peach Springs Canyon, which also drains part of the Truxton basin; Spencer creek, an informally named perennial stream within Spencer Canyon that drains the Spencer, Milkweed, Meriwhitica, and Hindu Canyons; Lost Creek, which drains Clay Tank Canyon; Reference Point Creek, which drains Horse Flat Canyon; and Quartermaster Canyon (fig. 1). Both Spencer creek and Peach Springs Wash have perennial reaches with substantial flow. The majority of perennial flow in Spencer creek originates from springs, which issue from the Rampart Cave Member of the Muav Limestone (Mason, Bills, and others, 2020). Lesser amounts of flow come from sediments and (or) volcanic rocks in the upper parts of Milkweed and West Water Canyons. Groundwater discharge to upper Peach Springs Wash is derived from older sediments and lakebed deposits of the Truxton aquifer and the Muav Limestone and Bright Angel Shale (Billingsley and others, 2006; Bills and Macy, 2016). Perennial flow comes into the lower reach of Peach Springs Wash from Diamond Creek, which flows out of the Coconino Plateau. Numerous other springs issuing from the Rampart Cave Member of the Muav Limestone flow for a short distance in many other canyons of the Hualapai Plateau.

Older basin-fill sediments of the Truxton basin make up the largest part of the Truxton aquifer. The younger basin-fill sediments exposed at the land surface in the Truxton basin are largely unsaturated but at least moderately permeable, and some coarser-grained sediments near the base of the younger basin-fill sediments are water bearing in parts of the basin (Bills and Macy, 2016). The Hurricane Fault, which bisects the Truxton basin, has created a greater thickness of basinfill sediments to the west of the fault (figs. 1 and 3 of Mason, Bills, and others, 2020). Well logs from near the community of Peach Springs, Ariz., and Truxton Wash indicate that the basin-fill sediments are dry on the east side of the Hurricane Fault and groundwater is found in the underlying Redwall or Muav limestones (Bills and Macy, 2016).

Usable groundwater on the Hualapai Plateau is in either perched water-bearing zones close to the surface or in the Muav Limestone at depths of greater than 2,000 ft below land surface. Perched water-bearing zones on the plateau occur in paleochannel-fill sediments, volcanic rocks, and (or) recent channel alluvium (Twenter, 1962). Groundwater in the Muav Limestone aquifer is found in the Rampart Cave Member of and near the bottom of the Muav Limestone (Twenter, 1962; Mason, Macy, and others, 2020). The Muav Limestone aquifer is incised by deep canyons on the plateau and truncated by the Colorado River. This results in discharge from the aquifer as springs in plateau canyons and along the Colorado River in 
the Grand Canyon. Although water flows out of the base of the Muav Limestone from several springs in canyons dissecting the Hualapai Plateau, the unit is not saturated in all areas of the plateau. Test wells drilled on the plateau through the Muav Limestone found the limestone to be dry (Mason, Macy, and others, 2020). Limited groundwater under artesian pressure was observed in these test wells below the Muav Limestone in the Bright Angel Shale and Tapeats Sandstone (Mason, Macy, and others, 2020).

\section{Conceptual Model of the Truxton Basin Groundwater System}

Most of the northeastern and western peripheral boundaries of the groundwater flow system in the Truxton basin are defined by hydrogeologic unit outcrops, with the eastern and southeastern boundaries defined by topographic and presumed groundwater divides. The saturated older basin-fill sediments of Tertiary age compose the Truxton aquifer. The partially consolidated to consolidated gravel, sand, and clay sediments are moderately permeable and generally saturated west of the Hurricane Fault. The Peach Springs supply wells, herein referred to as the Truxton well field, has pumped a modest volume of groundwater (less than 200 acrefeet per year) from this aquifer to provide municipal supply since 1976 (NRCE, 2011). The basin-fill sediments overlie Proterozoic crystalline and metamorphic basement rock that was denuded of Paleozoic and Mesozoic cover during and following the Laramide uplift. The Proterozoic crystalline and metamorphic basement rock is considered impermeable except where fractured.

Most inflow to the Truxton basin occurs as underflow from the saturated lower Paleozoic units of the eastern Hualapai Plateau that are in contact with the basin-fill sediments. Additional water enters the lower half of the Truxton basin from the northwest as mountain front recharge coming off the Music Mountains. Very little water is thought to enter the groundwater system through aerial recharge directly because of low precipitation and high potential evaporation rates.

Outflow from the basin occurs as discharge to Truxton Wash in the south, underflow to the north, and withdrawals from the Truxton well field. A groundwater divide is presumed to be located along the short axis and somewhere in the upper third of the basin.

\section{Hydrostratigraphic Framework Development}

Geophysical surveys were conducted to improve constraints on the geometry of significant hydrostratigraphic contacts in the Truxton basin and Hualapai Plateau. An airborne electromagnetic (AEM) survey was conducted over the full groundwater model domain, resulting in new highresolution resistivity models of the upper 300 to $600 \mathrm{~m}$ across the region, with a more detailed focus area around the Truxton basin. These models were used to develop three-dimensional interpretations of the base of the Muav Limestone and Truxton aquifers. The interpretations integrate observations of stratigraphic contacts in outcrop, lithologic descriptions from available wells, and mapped surface geology. In the deepest parts of the Truxton basin, where the contact between the basin-fill sediments and the crystalline basement lies below the resolution limits of the AEM survey, models of the top of bedrock were derived from new and existing gravity data and were integrated into the interpretation of the Truxton aquifer's base. The improved hydrostratigraphy better defines the geometry of paleochannels that control the thickness and shape of the Truxton aquifer and captures the regional geometry of major faults and monoclines in the base of aquifers and basement surfaces.

\section{Simulation of Current Conditions and Changes to the Truxton Aquifer}

A three-dimensional, numerical groundwater-flow model of the Truxton basin was developed to evaluate the current conceptual understanding of the Truxton basin groundwater system and estimate potential effects of projected groundwater withdrawals on groundwater levels and storage in the basin. The Truxton Basin Hydrologic Model (TBHM) was developed using previously published data as well as a new improved hydrostratigraphic framework (Ball, 2020). Processes simulated in the model include groundwater recharge, groundwater withdrawals from pumping, groundwater discharge to springs,

Table 1. Estimated predevelopment groundwater-budget values for western Hualapai Plateau, eastern Hualapai Plateau, and Truxton basin.

[Acre-ft/yr, acre-feet per year; n/a, not applicable]

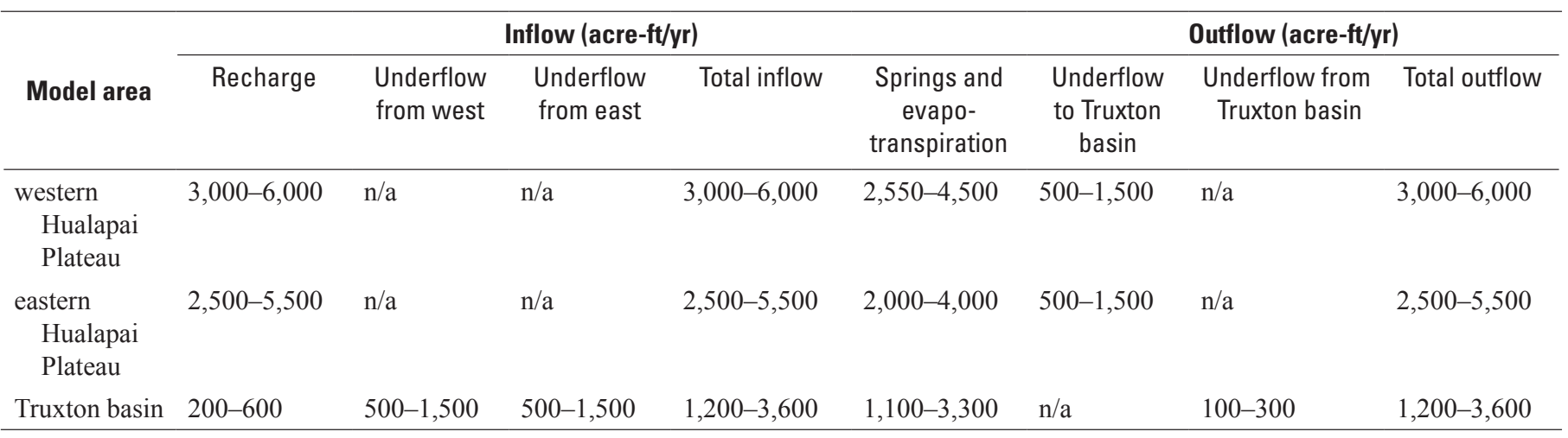


and riparian evapotranspiration (fig. 3). TBHM was developed using the USGS groundwater-flow model MODFLOW-NWT Version 1.1.4 (Niswonger and others, 2011). Automated parameter estimation was performed using PEST++ Version 4.2.5 (White and others, 2019). TBHM is a transient model that simulates the hydrologic system between the years 1976-2140 that is discretized into 13 stress periods and includes three hypothetical groundwater withdrawal scenarios between 2020-2140. The three-dimensional TBHM grid is 4 layers by 208 rows by 333 columns, with over half of the cells in the model grid inactive. Model cells are 984.25 by $984.25 \mathrm{ft}$ ( 300 by $300 \mathrm{~m}$ ) with variable thickness based on interpolated

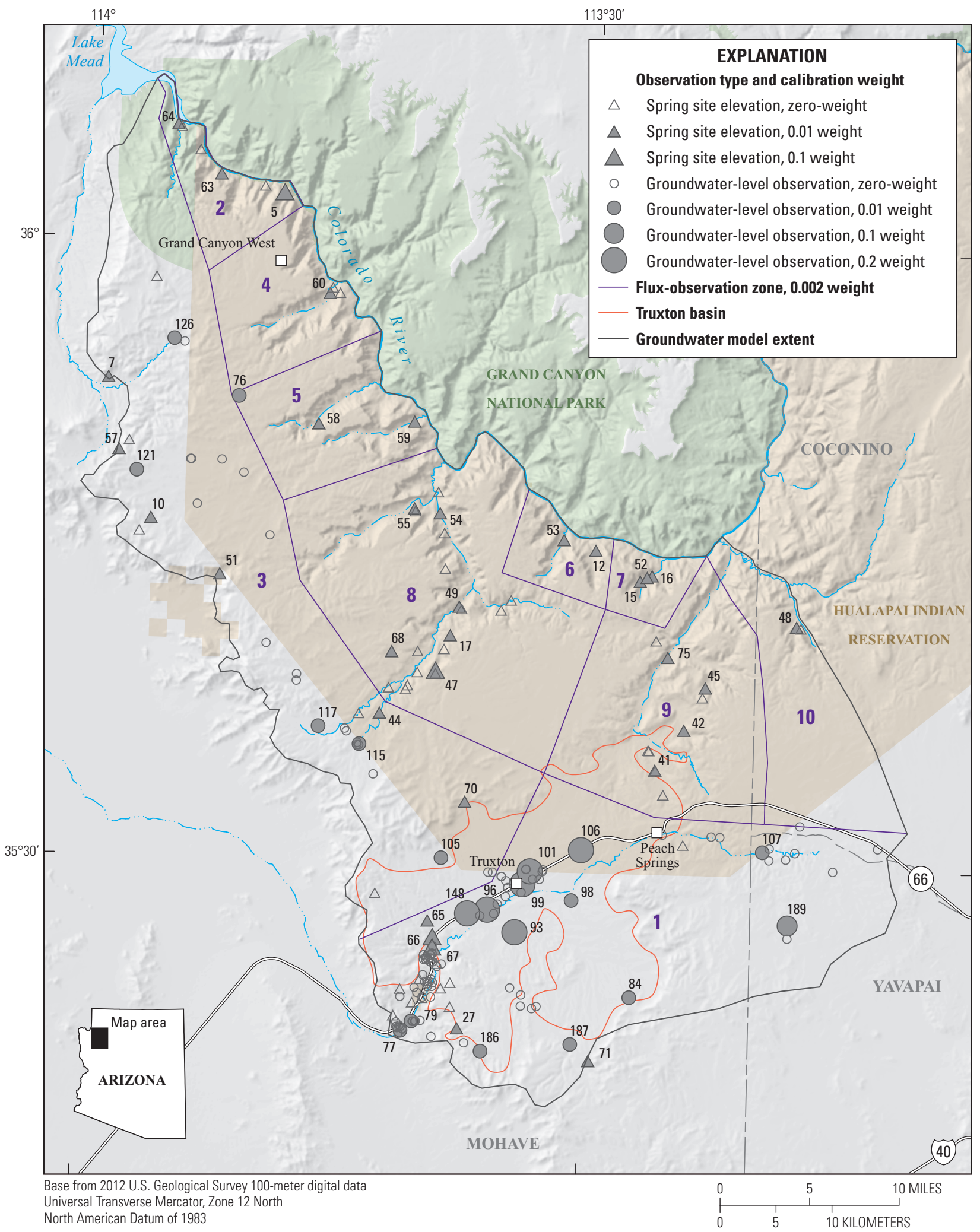

Figure 3. Map showing well and spring locations and observation zones simulated in the Truxton Basin Hydrologic Model. 
surface elevations of hydrostratigraphic units. Horizontal dimensions were chosen to match the general character of the interpreted hydrostratigraphy described in Ball (2020).

TBHM parameters of horizontal hydraulic conductivity, vertical hydraulic conductivity, horizontal anisotropy, specific yield, and specific storage were calibrated to available groundwater level observations from wells and spring elevations and to groundwater discharge estimates from spring flow and evapotranspiration. Parameter values were allowed to vary within ranges based on previously published information. For the calibration process, calibration targets were assigned weights based on a qualitative assessment of the observation's appropriate influence on the model. TBHM was iteratively calibrated to match target heads and flows first by manual trial and error and then by automated parameter estimation using PEST.

Final calibrated values of parameters adjusted in the automated estimation process were generally in agreement with the ranges of values identified in the conceptual model. Groundwater levels simulated by the calibrated model were comparable to groundwater-level observations with the spread of residuals (estimated minus simulated) generally in line with the uncertainty of the observations (fig. 4). The largest unweighted residuals are associated with groundwater levels in wells at higher elevations that were presumed to be in isolated perched systems that are disconnected from main area of interest for this study (fig. 5). Simulated groundwater discharge was higher than the estimated discharge in some observation zones and lower in others (fig. 6). Discharge estimates had a high degree of uncertainty, and the target fluxes were assigned a correspondingly low weight. Simulated groundwater level contours and resulting groundwater flow directions were generally in agreement with the conceptual model of the groundwater system (fig. 7). Simulated groundwater head gradients on the western Hualapai Plateau were steep and aligned with the regional dip of the strata to the northeast. Simulated gradients on the eastern Hualapai Plateau were less steep and did not correlate with strata dip direction. Simulated groundwater flow from recharge areas at the south margin of the model domain flowed to the east and north toward discharge locations in Diamond Creek. Simulated groundwater levels had essentially zero gradient in the majority of Truxton basin except where groundwater discharges to Truxton Wash on the southwest end and where water exits the basin as underflow on the northeast end. Whereas the calibrated model simulates groundwater flow from recharge to discharge areas in general agreement with current understanding of the groundwater system, it does not accurately simulate the rate of groundwater discharge at known spring locations.

Forecasted potential changes in groundwater levels and storage were based on projected future groundwater withdrawals in the basin by using the calibrated TBHM. Reclamation provided three potential future scenarios of groundwater withdrawals in the Truxton basin. Withdrawals from the existing Truxton well field increase at different rates in each scenario based on low, medium, and high projections of population growth and water needs. Withdrawals from a proposed new well (fig. 8) remain constant in all scenarios. Results from forecast simulations using the maximum future pumping scenario, a set of model parameters selected through

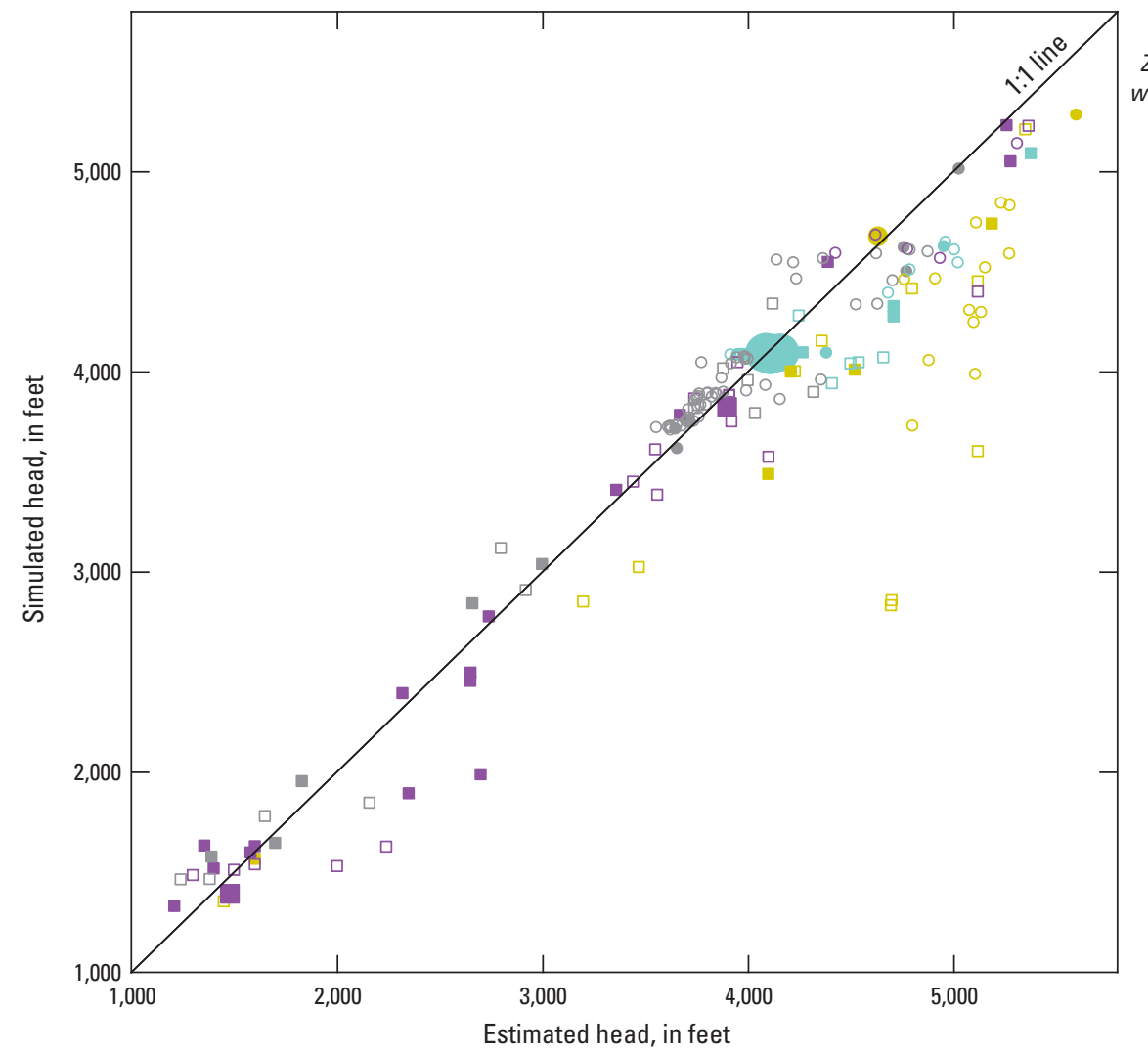

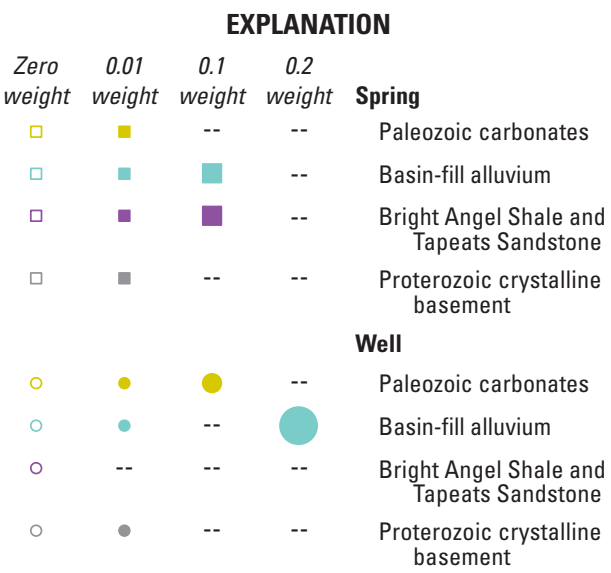

Figure 4. Scatterplot graph showing estimated versus simulated groundwater heads, plotted by hydrostratigraphic unit. The -- symbol represents a combination of weight and rock that are not shown on the graph. 


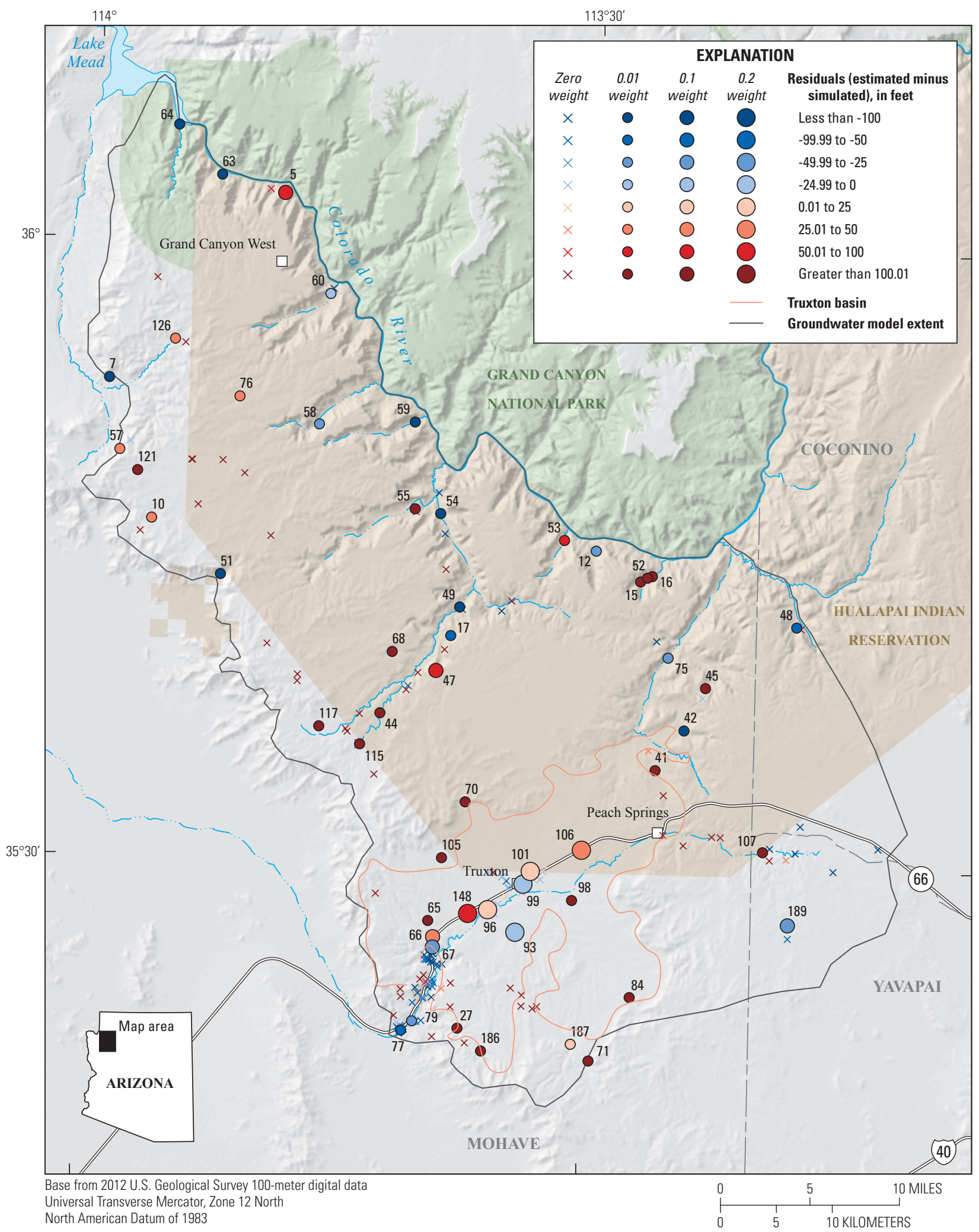

Figure 5. Map showing head target residuals (estimated minus simulated), in feet, from the calibrated Truxton Basin Hydrologic Model. The size of marker indicates the relative calibration weight applied $(0.0,0.01,0.1,0.2)$. 


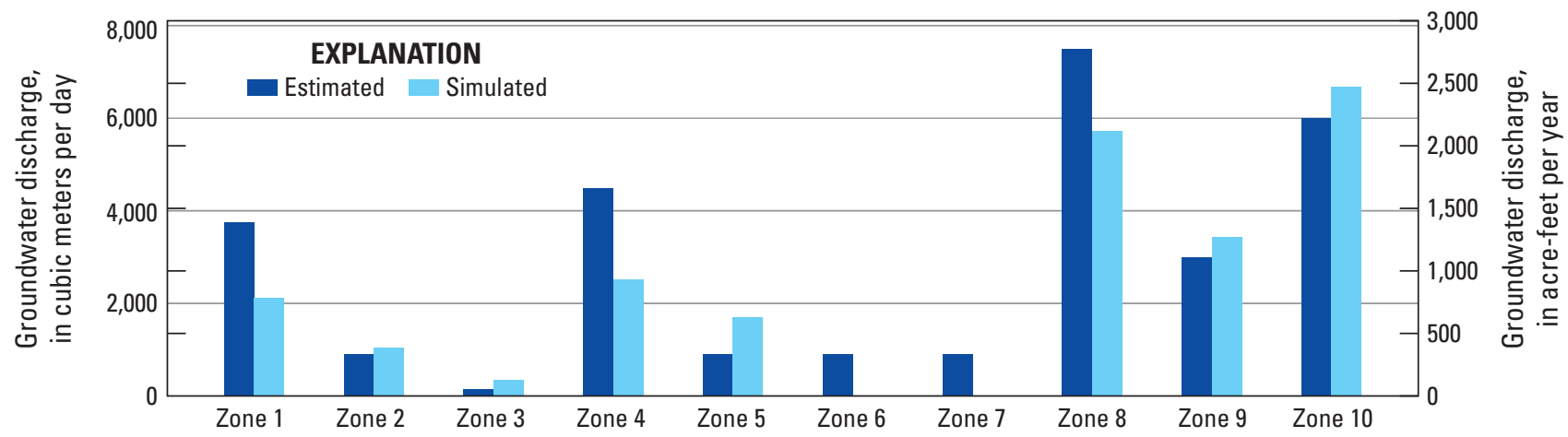

Figure 6. Bar graph showing estimated flux targets and simulated equivalents of total groundwater discharge by flux-observation zone.

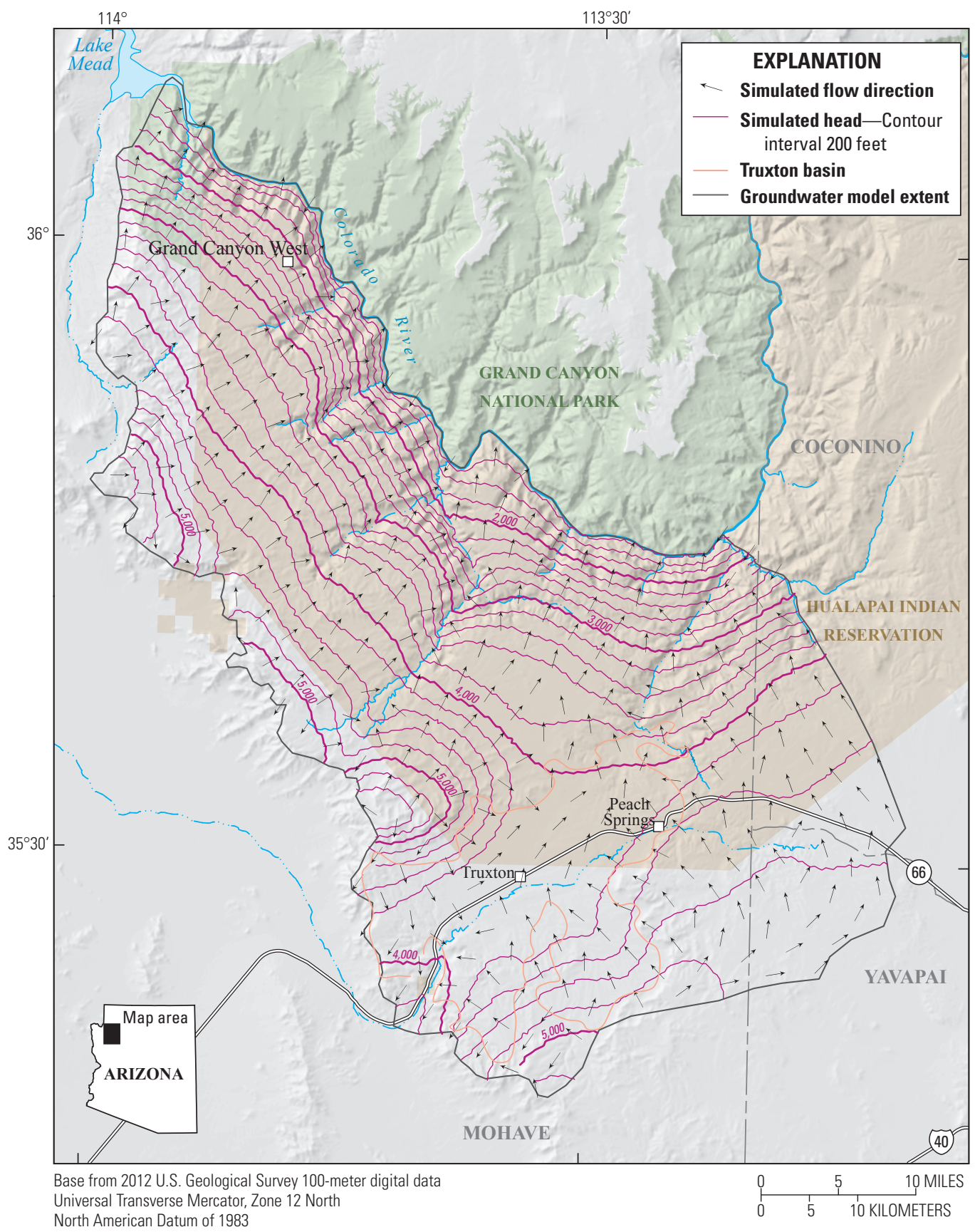

Figure 7. Map showing Truxton Basin Hydrologic Model simulated groundwater head contours and flow directions. 
the manual and automated parameter estimation process, and literature values for aquifer storage properties indicates about $28 \mathrm{ft}$ of groundwater level decline (compared to 2020 groundwater levels) near the pumping centers in the Truxton basin by 2140 (fig. 8).

Forecasted groundwater responses to groundwater withdrawals are highly sensitive to the hydraulic conductivity and storage parameters in the model. To address the uncertainty in aquifer properties in response to withdrawals, the forecasts of groundwater level changes are presented as a range of probable outcomes that result from the withdrawal scenarios. These outcomes were produced using the Monte

A

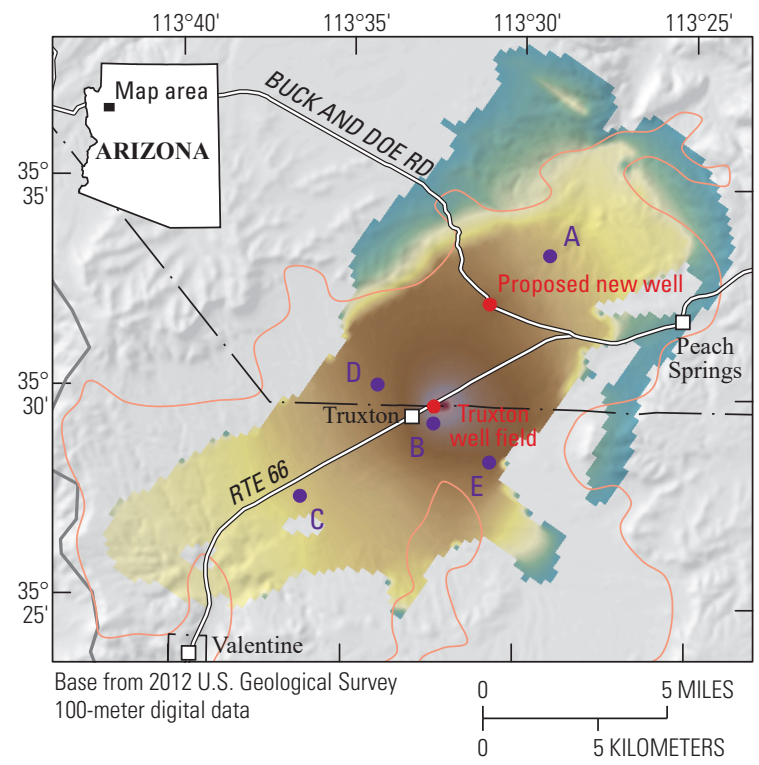

\section{EXPLANATION}

Simulated drawdown, in feet

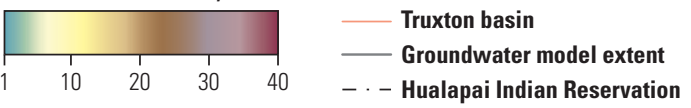

\section{B}

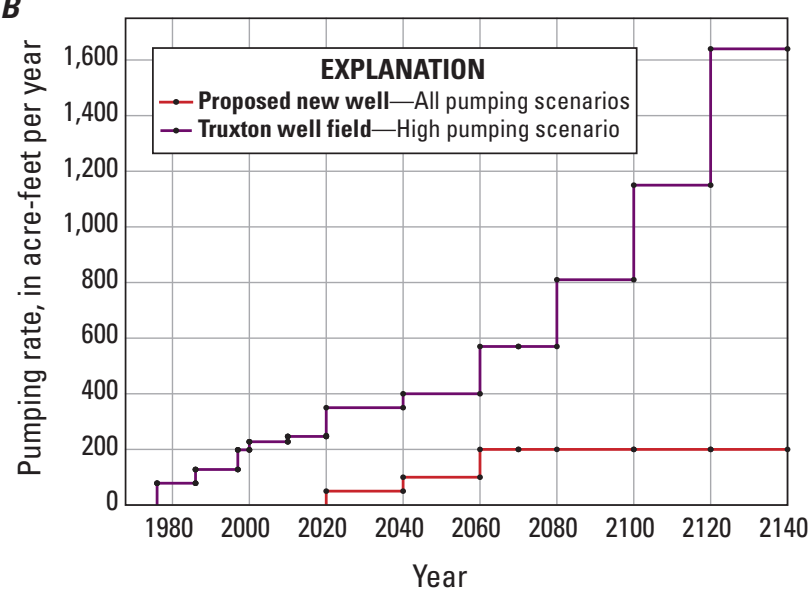

Figure 8. Map showing simulated drawdown from 2020 to 2140 for the high pumping scenario using the primary bedrock depth, in feet $(A)$ and simulated pumping rates at the Truxton well field and proposed new well in the high pumping scenario $(B)$.
Carlo method, wherein an ensemble of models is run using parameter values drawn from within a range of hydrologically reasonable values. Storage property values are drawn from a normal distribution built using the initial estimate as the mean and the estimated lower and upper bounds as the \pm 3 standard deviations. Future recharge rate was likewise varied by drawing a multiplying factor from a distribution between 0.75 and 1.25. Parameter values were randomly drawn from their calculated or prescribed distributions to create 10,000 unique groundwater flow model simulations. These ensemble simulations produced a median drawdown of about $28 \mathrm{ft}$ from 2020 to 2140 at the Truxton basin pumping center (fig. 9), within a range of about $20-39 \mathrm{ft}$ at the location.

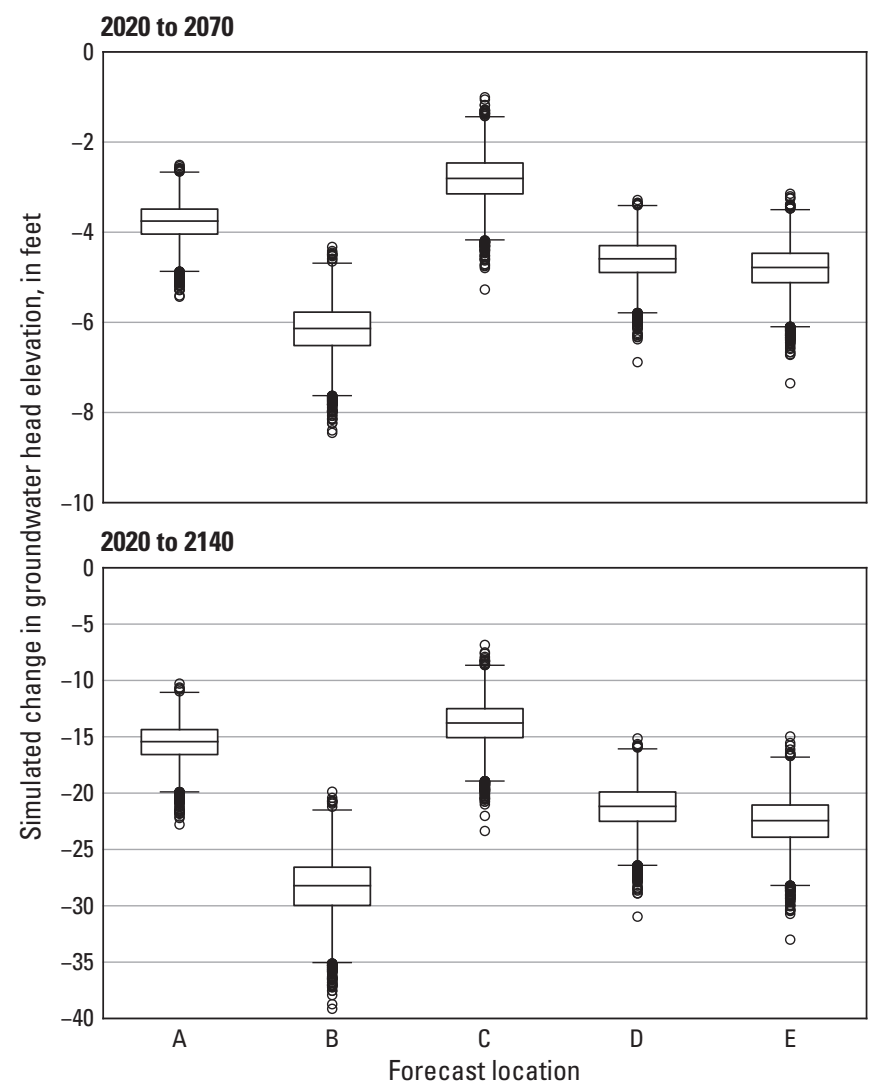

EXPLANATION

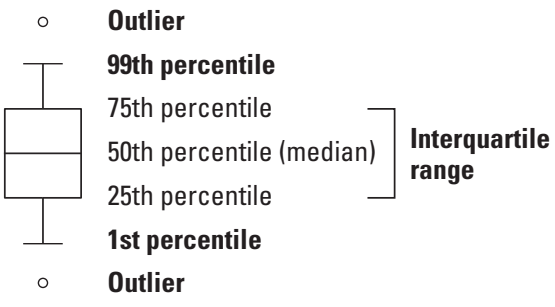

Figure 9. Boxplot diagrams showing the distribution of simulated groundwater level decline from 2020 levels for the high pumping scenario using the medium bedrock depth model at year 2070 and year 2140 at five pumping scenario locations (A through $E$ ) in the Truxton basin. Locations of wells are shown in figure $8 A$. 


\section{Summary and Conclusions}

The Hualapai Tribe of northwestern Arizona is seeking reliable and sustainable water resources to meet the projected long-term needs for the reservation. Since 2015 the USGS has conducted a series of investigations on and near the Hualapai Indian Reservation to evaluate groundwater resources in the area. Results from earlier investigations describe the hydrologic framework and characterization of the Truxton aquifer on the Hualapai Indian Reservation (Bills and Macy, 2016) and the hydrogeologic characterization of the Hualapai Plateau part of the reservation (Mason, Macy, and others, 2020). This report investigates the availability of groundwater in the Truxton aquifer both on and adjacent to the Hualapai Indian Reservation. This assessment of groundwater availability in the Truxton aquifer consists of collection, integration, and use of both new and existing hydrogeologic and geophysical data. These data are used to construct and calibrate a finite-difference numerical groundwater-flow model to simulate groundwater flow in the Truxton aquifer over the 1976-2140 time period, with a primary goal of evaluating possible changes in the groundwater system resulting from projected increases in groundwater pumping from the aquifer.

Simulated groundwater level contours and resulting groundwater flow directions produced by the Truxton Basin Hydrologic Model are generally in agreement with the conceptual model of the groundwater system. Simulated groundwater flow from recharge areas at the southwest and southeast margins of the model domain mostly flow to discharge locations in the tributary canyons of the Grand Canyon. A smaller volume of water flows from these areas into the saturated sediments of the Truxton basin. A minor amount of recharge is simulated to the southwestern end of the basin. Simulated groundwater levels have essentially zero gradient in the majority of Truxton basin except where groundwater discharges to Truxton Wash on the southwest end and where water exits the basin as underflow on the northeast end. The calibrated groundwater flow model was used to forecast potential changes in groundwater levels and storage based on three projected future groundwater withdrawal scenarios in the basin. Withdrawals from the existing Truxton well field increase at different rates in each scenario based on low, medium, and high projections of population growth and water needs. Results from forecast simulations using the maximum future pumping scenario, a set of model parameters selected through the manual and automated parameter estimation process, and literature values for aquifer storage properties indicate about $28 \mathrm{ft}$ of water-level decline near the pumping centers in the Truxton basin from 2020 to 2140. To address the effect of uncertainty in aquifer properties on model forecasts of groundwater level changes in response to groundwater withdrawals, Monte Carlo simulations were run using ranges of aquifer property values. Parameter values were randomly drawn from their calculated or prescribed distributions to create 10,000 unique groundwater-flow model simulations. These ensemble simulations produced a median drawdown of $28 \mathrm{ft}$ from 2020 to 2140 at the Truxton basin pumping center within a range of $20-39 \mathrm{ft}$ at that location.

The Truxton Basin Hydrologic Model is not intended to simulate current or future discharge from specific spring locations that could be impacted by potential future withdrawals or changes in climate. Forecasted groundwater levels are strongly correlated with simulated future recharge. Repeated inventory of major spring discharges will help reduce uncertainty of estimated recharge rates.

\section{References Cited}

Arizona Bureau of Geology and Mineral Technology, 1988, Geologic map of Santa Fe Railroad Company mineral holdings in northwestern Arizona: Arizona Bureau of Geology and Mineral Technology Miscellaneous Map MM-88A, scale 1:250,000.

Arizona Department of Water Resources, 2009, Arizona water atlas volume 4; Upper Colorado River Planning AreaSection 4.8, Peach Springs Basin: Arizona Department of Water Resources, p. 323-351.

Ball, L.B., 2020, Major hydrostratigraphic contacts of the Truxton basin and Hualapai Plateau [of the western Grand Canyon region], northwestern Arizona, developed from airborne electromagnetic data, chap. D of Mason, J.P., ed., Geophysical surveys, hydrogeologic characterization, and groundwater flow model for the Truxton basin and Hualapai Plateau, northwestern Arizona: U.S. Geological Survey Scientific Investigations Report 2020-5017, 24 p., available at https://doi.org/10.3133/sir20205017D.

Beard, L.S., and Lucchitta, I., 1993, Geologic map of the Valentine Southeast quadrangle, Mohave County, Arizona: U.S. Geological Survey Geologic Quadrangle Map 1711, scale 1:24,000, accessed January 17, 2020 at https:// ngmdb.usgs.gov/Prodesc/proddesc_1216.htm.

Billingsley, G.H., Block, D.L., and Dyer, H.C., 2006, Geology of the Peach Springs 30' $\times 60^{\prime}$ quadrangle, Mohave and Coconino Counties, northwestern Arizona: U.S. Geological Scientific Investigations Map 2900, 16 p., 1 plate, scale 1:100,000, accessed January 2019 at https://pubs.usgs.gov/ $\operatorname{sim} / 2006 / 2900 /$.

Billingsley, G.H., Wenrich, K.J., Huntoon, P.W., and Young, R.A., 1986, Breccia-pipe and geologic map of the southeastern Hualapai Indian Reservation and vicinity, Arizona: U.S. Geological Survey Open-File Report 86-458B, scale 1:48,000, includes 26-p. pamphlet., available at https://doi.org/10.3133/ofr86458B.

Billingsley, G.H., Wenrich, K.J., Huntoon, P.W., and Young, R.A., 1999, Breccia-pipe and geologic map of the southwestern part of the Hualapai Indian Reservation and vicinity, Arizona: U.S. Geological Survey Miscellaneous Investigations Series Map I-2554, scale 1:48,000, 2 plates, 50 p. 
Bills, D.J., and Macy, J.P., 2016, Hydrologic framework and characterization of the Truxton aquifer on the Hualapai Reservation, Mohave County, Arizona (ver. 2.0, December 2017): U.S. Geological Survey Scientific Investigations Report 2016-5171, 50 p., https://doi.org/10.3133/ $\operatorname{sir} 20165171$.

Darton, N.H., 1910, A reconnaissance of parts of northwestern New Mexico and northern Arizona: U.S. Geological Survey Bulletin 435, 88 p., available at https://pubs.usgs.gov/ bul/0435/report.pdf.

Darton, N.H., 1915, Guidebook of the western United StatesPart C, the Santa Fe Route: U.S. Geological Survey Bulletin 613, 194 p., available at https://doi.org/10.3133/b613.

Darton, N.H., 1925, A resume of Arizona geology: Arizona Bureau of Mines Bulletin 119, 298 p.

Dutton, C.E., 1882a, The physical geology of the Grand Cañon district in U.S. Geological and Geographical Survey Territory, Second Annual Report: Washington, Government Printing Office, p. 47-166.

Dutton, C.E., 1882b, Tertiary history of the Grand Cañon district: Tucson, University of Arizona Press, 264 p.

Elston, D.P. and Young, R.A., 1991. Cretaceous-Eocene (Laramide) landscape development and Oligocene-Pliocene drainage reorganization of transition zone and Colorado Plateau, Arizona. Journal of Geophysical Research: Solid Earth, v. 96, no. B7, p. 12389-12406.

Farnsworth, R.K., Thompson, E.S., and Peck, E.L., 1982, Evaporation atlas for the contiguous 48 United States: National Oceanographic and Atmospheric Administration Technical Report National Weather Service Series 33, 26 p.

Fenneman, N.M., 1931, Physiography of the western United States: New York, McGraw-Hill, 534 p.

Freethey, G.W., and Anderson, T.W., 1986, Predevelopment hydrologic conditions in the alluvial basins of Arizona and adjacent parts of California and New Mexico: U.S. Geological Survey Hydrologic Investigations Atlas HA-664, 3 plates, scale 1:500,000, available at https://doi.org/10.3133/ha664.

Freethey, G.W., Pool, D.R., Anderson, T.W., and Tucci, P., 1986, Description and generalized distribution of aquifer materials in the alluvial basins of Arizona and adjacent parts of California and New Mexico: U.S. Geological Survey Hydrologic Investigations Atlas HA-663, 4 plates, scale 1:500,000, available at https://doi.org/10.3133/ha663.

Hualapai Department of Natural Resources, 2010, Western Hualapai Plateau and Spencer creek watershed management-Special water study, Hualapai Reservation: Hualapai Department of Natural Resources, 52 p.
Hualapai Department of Natural Resources, 2015, Water management plan for the Truxton Canyon Wash and Peach Springs Canyon watersheds: Hualapai Department of Natural Resources, 100 p.

Hualapai Water Resources Program, 1999, Hualapai Reservation water quality assessment report 305(b): Prepared for the Hualapai Tribal Council by the Hualapai Water Resources Program with technical assistance from the U.S. Geological Survey, July 1999, 103 p.

Hualapai Water Resources Program, 2004, Hualapai Reservation water quality assessment report 305(b): Prepared for the Hualapai Tribal Council by the Hualapai Water Resources Program with technical assistance from the U.S. Geological Survey, July 2005, 223 p.

Hualapai Water Resources Program, 2009, Hualapai Reservation water quality assessment report 305(b): Prepared for the Hualapai Tribal Council by the Hualapai Water Resources Program with assistance from the U.S. Geological Survey, July 2009, 102 p.

Kennedy, J.R., 2020, Gravity surveys and depth to bedrock in the Truxton basin, northwestern Arizona, chap. C of Mason, J.P., ed., Geophysical surveys, hydrogeologic characterization, and groundwater flow model for the Truxton basin and Hualapai Plateau, northwestern Arizona: U.S. Geological Survey Scientific Investigations Report 2020-2017, 10 p., available at https://doi.org/10.3133/ sir20205017C.

Knight, J.E., 2020, Simulation of groundwater-level changes from projected groundwater withdrawals in the Truxton basin, northwestern Arizona, chap. E of Mason, J.P., ed., Geophysical surveys, hydrogeologic characterization, and groundwater flow model for the Truxton basin and Hualapai Plateau, northwestern Arizona: U.S. Geological Survey Scientific Investigations Report 2020-5017, 39 p., available at https://doi.org/10.3133/sir20205017E.

Koons, E.D., 1945, Geology of the Uinkaret Plateau, northern Arizona: Geological Society of America Bulletin, v. 56, no. 2, p. 151-180.

Koons, E.D., 1948a, Geology of the eastern Hualapai Reservation: Plateau, v. 20, no. 4, p. 53-60.

Koons, E.D., 1948b, High level gravels of western Grand Canyon: Science, v. 107, no. 2784, p. 475-476.

Lee, W.T., 1908, Geologic reconnaissance of a part of western Arizona: U.S. Geological Survey Bulletin 352, 107 p., available at https://doi.org/10.3133/b352.

Mason, J.P., Macy, J.P., Bills, D.J., Gungle, B., and Jones, C.J., 2020, Hydrologic characterization of the Hualapai Plateau on the western Hualapai Indian Reservation, Mohave County, Arizona: U.S. Geological Survey Scientific Investigations Report 2020-5025, 38 p., https://doi. org/10.3133/sir20205025. 
Mason, J.P., Bills, D.J., and Macy, J.P., 2020, Geology and hydrology of the Truxton basin and Hualapai Plateau, northwestern Arizona, chap. B of Mason, J.P., ed., Geophysical surveys, hydrogeologic characterization, and groundwater flow model for the Truxton basin and Hualapai Plateau, northwestern Arizona: U.S. Geological Survey Scientific Investigations Report 2020-5017, 9 p., available at https://doi.org/10.3133/sir20205017B.

McKee, E.D., 1934, The Coconino Sandstone-Its history and origin, in Papers concerning the palaeontology of California, Arizona, and Idaho: Carnegie Institution of Washington, Publication 440, p. 77-135.

McKee, E.D., 1938, The environment and history of the Toroweap and Kaibab Formations of northern Arizona and southern Utah: Carnegie Institution of Washington, Publication 492, $268 \mathrm{p}$.

McKee, E.D., 1945, Stratigraphy and ecology of the Grand Canyon Cambrian, part 1, in McKee, E.D. and Resser, C.E., eds., Cambrian history of the Grand Canyon region: Carnegie Institution of Washington, Publication 563, p. 3-168.

Myers, S.M., 1987, Map showing groundwater conditions in the Peach Springs basin, Mohave, Coconino, and Yavapai Counties, Arizona - 1987: Arizona Department of Water Resources Hydrologic Map Series Report 15, 1 plate, scale 1:125,000.

Natural Resources Consulting Engineers (NRCE), 2011, Evaluation of the Peach Springs groundwater supply on the Hualapai Reservation: Prepared for the Hualapai Tribal Council by Natural Resources Consulting Engineers, Inc., $102 \mathrm{p}$.

Niswonger, R. G., Panday, S., and Ibaraki, M. 2011, MODFLOW-NWT, A Newton formulation for MODFLOW-2005: U.S. Geological Survey Techniques and Methods 6-A37, $44 \mathrm{p}$.

PRISM Climate Group, 2020, PRISM climate data: Northwest Alliance for Computational Science and Engineering, Oregon State University, accessed February 19, 2020, at http://prism.oregonstate.edu.

Remick, W.H., 1981, Map showing ground-water conditions in the Hualapai Basin area, Mohave, Coconino, and Yavapai Counties, Arizona - 1980: Arizona Department of Water Resources Hydrologic Map Series Report 4, 1 plate, scale 1:125,000.

Reynolds, S.J., 1997, Geologic map of Arizona: Arizona Geological Survey Map M-35, 1 sheet, scale 1:1,000,000.
Richard, S.M., Reynolds, S.J., Spencer, J.E., and Pearthree, P.A., comps., 2000, Geologic map of Arizona: Arizona Geological Survey Map M-35, 1 sheet, scale 1:1,000,000, accessed January 17, 2020, at http://repository.azgs.az.gov/ uri_gin/azgs/dlio/1705.

Schrader, F.C., 1909, Mineral deposits or the Cerbat Range, Black Mountains, and the Grand Wash Cliffs, Mohave County, Arizona: U.S. Geological Survey Bulletin 397, 226 p., available at https://doi.org/10.3133/b397.

Sellers, W.D., Hill, R.H., and Sanderson-Rae, M., eds., 1985, Arizona climate the first hundred years, 1885-1985: Tucson, University of Arizona Press, 143 p.

Twenter, F.R., 1962, Geology and promising areas of groundwater development in the Hualapai Reservation, Arizona: U.S. Geological Water-Supply Paper 1576-A, 1 plate, 38 p., available at https://doi.org/10.3133/wsp1576A.

Wenrich, K.J., Billingsley, G.H., and Huntoon, P.W., 1996, Breccia-pipe and geologic map of the northwestern part of the Hualapai Indian Reservation and vicinity, Arizona: U.S. Geological Survey Geologic Investigations Map I-2522, 2 pls., scale 1:48,000, 16 p., available at https://doi.org/10.3133/i2522.

Wenrich, K.J., Billingsley, G.H., and Huntoon, P.W., 1997, Breccia-pipe and geologic map of the northeastern part of the Hualapai Indian Reservation and vicinity, Arizona: U.S. Geological Survey Miscellaneous Investigations Series I-2440, scale 1:48,000, 19 p., available at https://doi.org/10.3133/i2440.

Western Region Climate Center, 2015, Western Region Climate Center website: Western Region Climate Center, accessed February 2018 at http://www.wrcc.dri.edu/ summary/Climsmaz.html.

White, J., Welter, D., and Doherty, J., 2019, PEST++ (ver. 4.2.5): U.S. Geological Survey GitHub web page, accessed April 2019 at https://github.com/usgs/pestpp.

Wilson, E.D., and Moore, R.T., 1959, Geologic map of Mohave County, Arizona: Prepared by the Arizona Bureau of Mines and University of Arizona, Tucson, 1 plate, scale 1:375,000.

Young, R.A., 2007, The geology and hydrology of Tertiary groundwater aquifers and the impact of shallow rock quarrying in upper Milkweed Canyon: Special Report to the Cultural Resources Department, Hualapai Tribe, 25 p. 
Menlo Park Publishing Service Center, California

Manuscript approved for publication February 18, 2020 Edited by Phil A. Frederick

Layout and design by Kimber Petersen and Cory Hurd Illustration support by JoJo Mangano 
웅

9

言

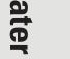



홍

콜

명.

2

हె

要

ㄱ.

i

cs

$\bar{\Phi}$.

言

$\bar{\Sigma}$

$\stackrel{\mathbb{S}}{\stackrel{0}{1} .}$

苛.

क

疋

윽

్ㅗㅇ

G

I

3

3.

్ㅗㅇ 